\title{
Does the Jurisdiction of the California Railroad Commission Extend to Air Transportation?
}

\author{
Theodore E. Wolcott*
}

TN THE period following 1870 the Granger Movement influenced many states to pass laws prohibiting unreasonable railroad rates, discriminations and practices. ${ }^{1}$ Commissions were created to administer and enforce these statutes against the railroads. One of these was the California Railroad Commission. ${ }^{2}$ There does not appear to be anything else in the genesis of this Commission in 1879 which would warrant broademing its original compass beyond the specific need that produced it. The language of the constitutional and statutory provisions creating and implementing the Commission was functionally contrived. It set up a special kind of agency to regulate in a limited way a transportation medium that was then causing the people concern. Controlled regulatory growth was later specifically provided for by endowing the legislature with authority to enlarge the Commission's powers and orbit as it saw fit. Nowhere in its origins (at a time when the entire country was at the threshold of a new and mighty transportation era) does it appear that the Commission was given a blank check on the future.

Being unknown to the common law, a public utility commission is conditioned by the terms of its creating statute, organic or legislative. ${ }^{3}$ These conditions mark the boundaries of its authority which

*Associated with the New York law firm of Pruitt, Hale and Coursen.

1 Jomnson, Huebner and Wisson, Transportation (1940) 206; Spurr, Guiding Princtiles of Public Service Regulation (1924) 11.

2 "It is a matter of common knowledge that among the evils, or supposed evils, under which the people of the State were suffering, and for which they demanded redress, was that of exorbitant and discrimimating charges by railroad corporations engaged in transportation of freight and passengers," Railroad Commission v. Market St. Ry. Co. (1901) 132 Cal. 677, 678, 64 Pac. 1065, 1065.

3 Motor Transit Co. v. State R. Comm. (1922) 189 Cal. 573, 209 Pac. 586; Chicago Railways Co. v. Commerce Commission (Illinois) (1929) 336 Ill. 51, 167 N.E. 840; Nashville, Chattanooga \& St. Louis Ry. v. R.Rd. \& Pub. Util. Com. (Tennessee) (1929) 159 Tenn. 43, 15 S.W. (2d) 751; and West v. Sun Cab Co. (Marylyand) (1931) 154 Atl. 100, P.U.R. 1931 C. 1. 
must be clear to sustain its exercise and they also delimit the kinds of utilities subject thereto. ${ }^{4}$

There has been no constitutional amendment or statutory enactment since 1879, either general or special, extending the Railroad Commission's jurisdiction to commercial air transportation. Such jurisdiction, if it exists at all, of necessity must be found in the intent, rather than the language of the originating laws. The absence in the original document of verbiage specifically descriptive of air transporation would require us to read into such general terms as there may be found, either a rare prophetic vision on the part of its framers, or an unusully broad delegation of the legislative power to an untried administrative agency,-or both. Nor would the fact that a public utilities commission was then a comparatively new type of governmental function make this distention easier. ${ }^{6}$

But, as we shall see, it so happens that the judicial, legislative and constitutional histories of the Railroad Commission combine to establish a consistent design. On the whole, a harmonious pattern emerges - of a contemporary, rather than an anticipatory, state regulation of the various transportation media (and other public utilities) as they appeared and developed. But such regulation ensued only if, and to the extent that, the people of California stated the necessity through specific legislative or constitutional enactment. ${ }^{7}$

The history of the Commission's authority falls into two stages. The period from 1879 to 1911, the year of the Commission's reorganization by constitutional and statutory amendment-and the modern period thereafter. The discussion following will therefore treat of these intervals separately.

$$
\text { A. } 1879 \text { то } 1911
$$

The Railroad Commission was created by Article XII of the California Constitution of 1879. Of this article, sections 17 to 24 are the

451 C. J. 37.

5 Webster Mfg. Co. v. Byrnes (1929) 207 Cal. 630, 280 Pac. 101.

6 Actually the first of the railroad commissions appeared in New England, beginning with New Hampshire and Rhode Island in 1844. This was followed by Connecticut in 1853, Vermont and New York in 1855, Maine in 1858, Ohio in 1867 and Massachusetts in 1869. However, these commissions were not concerned with discrimination in rates or services. The contemporary attitude is well described in the authorities cited in notes 1 and 2, supra.

7 This did not necessarily mean administration by a state agency, since as will presently appear, many local utilities are regulated by municipalities. 
only ones that need concern us here. In their original form the basic theme of these sections was the regulation of railroad and canal companies. Various rights, duties and liabilities of the railroads (and occasionally the canal companies) were detailed, but of no other transportation companies.

The language specifically creating the Commissions is found in section 22. The pertinent portion of the original section provides in part that "said commissioners shall have the power and it shall be their duty to establish rates of charges for the transportation of passengers and freight by railroad or other transportation companies". Section 23 as originally enacted in 1879 , in order to provide for the convenient exercise of the powers of the Railroad Commission, merely set forth the various geographic divisions of the state that made up the three railroad districts. ${ }^{8}$

Contemporaneously with the promulgation of these constitutional provisions, clarifying and organizational legislation was effected by the state legislature." The term "other transportation companies" was there specifically defined and limited to railroad, steamship and steamboat companies. ${ }^{10}$

Construction of the term "other transportation companies" invites the conventional technique of consideration of the surrounding circumstances and the general objectives involved in constitutional formulations - and corresponding interpretations, "but the implementing action of the legislature in sinultaneously defining "trans-

8 Generally the only substantive powers granted to the Commission were the powers to fix rates, prescribe a uniform system of accounts and to hear and determine complaints.

${ }^{9}$ Cal. Stats. 1880, pp. 45, 48; Moran v. Ross (1889) 79 Cal. 159, 21 Pac. 547. In Southern Pacific v. Board of Railroad Commissioners of California (1896) 78 Fed. 236, 251 (aff'd, 183 U.S. 497) this statute was noted as having been passed in aid of the constitution.

10 This section of the statutes of 1880 was set out in the opinion of the supreme court in Moran v. Ross, supra note 9: "The Act organizing and defining the powers of the board of railroad commissioners provicles: "The term "transportation companies" shall be deemed to mean and include: 1. All companies owning and operating railróads (other than street railroads) within this State; 2. All companies owming and operating steamships engaged $m$ the transportation of freight or passengers from and to ports within this State; 3 . All companies owning and operating steamboats used in transporting freight or passengers upon the rivers or inland waters of this State'."

11 Robertson v. Langford (1928) 95 Cal. App. 414, 273 Pac. 150; Bakkerson v. Superior Ct. of Los Angeles County (1925) 197 Cal, 504, 241 Pac. 874; Story v. Richardson (1921) 186 Cal. 162, 198 Pac. 1057; Union Tank Lime Co. v. Richardson (1920) 183 Cal. 409, 413, 191 Pac. 697, 699; Moran v. Ross, supra note 9. 
portation companies" removes the loose ends, if any. Under ordinary circumstances, legislative interpretation is generally deemed well nigh, if not completely, controlling. ${ }^{12}$ Here, the combination of contemporary events and positive legislative definition would seein to very clearly state the nature and extent of the power granted to the Commission in its inception.

The Board of Railroad Commissioners, as it was then called, with its "comparatively minor authority ... languished through 30 years of quite innocuous inpotence until ... 1911". ${ }^{13}$ This was understandable. There was little to regulate but railroads. The other public utilities were in the various stages of incubation. It was not until after the new century had been well launched that the motor vehicle became a factor to be reckoned with in transportation.

It was natural then, that the one really significant jurisdictional contest that arose durmg this period, did not concern any new form of transportation. But this contest involved a whittling down rather than an aggrandizement of the Commission's sphere of influence. In the Market Street Railway case decided in $1901,{ }^{14}$ the expression "other transportation companies" not only failed to perform a generic catch-all service, but lacked even the saving function of sustaining the generality of the primary term "railroad company". Although there was nothimg in sections 22 or 23 to suggest any territorial limitations (within the state) of the Commission's suzerainty, nevertheless that also was reduced as a result of that decision.

The issue as stated by the court involved the construction of sections 22 and 23: "Do the words, 'railroad and transportation companies' include a street railway company in a mumcipality, engaged in the business of carrying passengers on street-railroad cars?"

In holding that the Commission's jurisdiction did not extend to street railway companies, the court quite conventionally" looked "to the words used, the context, the object in view, and the evils that were intended to be remedied". Applying the rule of contemporane-

12 San Francisco v. Industrial Acc. Comm. (1920) 183 Cal. 273, 191 Pac. 26; Kaiser v. Hopkins (1936) 6 Cal. (2d) 537, 58 P. (2d) 1278; Pacific Indemnity Co. v. Industrial Acc. Comm. (1932) 215 Cal. 461, 11 P. (2d) 1; Spring Valley Co. v. Johnson (1935) 7 Cal. App. (2d) 258, 46 P. (2d) 294.

13 Wheat, Practice and Procedure Before the Railroad Commission of Califorria (1927) 15 Cartf. L. Rev. 445, 447.

14 Railroad Commission v. Market St. Ry. Co. (1901) 132 Cal. 677, 64 Pac. 1065.

15 See cases cited in notes 2 to 5 , supra. 
ous construction, it was found that the original purpose of the people was to prevent discriminatory rates and practices on the part of the "great corporations" engaged in statewide railroad carriage of both passengers and freight, and that it was this type of general long-haul railroad with its great economic impact that California was then interested in regulating rather than the limited or occasional carrier. Also noted as indicative of this and of an extra-municipal purpose was the division of the entire-state into only three railroad districts. Literal interpretation was further demonstrated to be specious by an exampling of the many types of public transportation which by their specialized or local nature could not have been intended to be subject to the supervision of the statewide and remote Railroad Commission. This included "companies engaged in draying, running freight wagons, delivery wagons, delivering parcels, teaming or running elevator". Weight was also given the statute of 1880 as a virtually simultaneous legislative interpretation.

The Market Street case succinctly summed up the Commission's origin, its purpose and its history. Separately or taken together, these factors spelled limited jurisdiction. It was not to be until 1911 that the people of California would make further grants to the Commission from their reserves of power and then the grants were to be made conditionally. This course was consistent, generally, with the evolution of state public utility commissions which, until nearly the beginning of the twentieth century, were concerned solely with the railroads..$^{16}$ In fact, "The modern period of state regulation may be said to have begun in 1907."17

\section{B. 1911 TO DATE}

On October 10, 1911, Sections 22 and 23 of Article XII of the California constitution were amended so as to provide for a reorganization of the Commission and an enlargement of its scope. ${ }^{18}$ But this time there was no direct grant of power to the Commission. The new authority was not self-executing. It was to be meted out in the legislature's discretion through enabling acts.

Section 22'was left substantially unchanged except that the legislature's function was implemented by a statement that "no provision

${ }^{16}$ SPURR, op. cit. supra note 1 , at 13.

1 Ibid. at 14.

18 East Bay M. U. Dist. v. Railroad Com. (1924) 194 Cal. 603, 608, 229 Pac. 949, 950. 
of the constitution shall be construed in limitation upon the authority of the legislature to confer upon the railroad commission additional powers". This authority was "expressly declared to be plenary and unlimited ....".

Section 23 underwent substantial amendment and it specifically enumerated the kinds of public utilities that were to be under the ultimate control of the Commission. "Every common carrier" was declared to be a "public utility". ${ }^{19}$ It also provided for the further broadening of the classifications of "public utilities" by the state legislature. However, it was stipulated that all of these "public utilities" could only be regulated by the railroad commission after and to the extent that the legislature expressly conferred the power. ${ }^{20}$ Section 23 was again amended in 1914 with little change except that it gave municipalities additional powers.

The reorganization was of a piece with the fundamental status of the Commission as one of limited powers. ${ }^{21}$

The new constitutional provisions were obviously bottomed on the assumption that hitherto the Commission's scope had been cir-

19 See concurring opinion of Sloss, J. in Pacific Telephone and Telegraph Co. v. Eshleman (1913) 166 Cal. 640, 690, 137 Pac. 1119, 1139.

20 Section 22 reads in part as follows: "... Said Commission shall haye the power to establish rates of charges for the transportation of passengers and freight by railroads and other transportation compamies, and no railroad or other transportation company shall charge or demand or collect or receive a greater or less or different compensation for such transportation of passengers or freight, or for any service in connection therewith, between the points named in any tariff of rates, established by said Commission, than the rates, fares and charges which are specified in such tariff. . . No provision of this Constitution shall be construed as a limitation upon the authority of the Legislature to confer upon the Railroad Commission additional powers of the same kind or different from those conferred herein which are not inconsistent with the powers conferred upon the Railroad Commission in this Constitution, and the authority of the Legislature to confer such additional powers is expressly declared to be plenary and unlimited by any provision of this Constitution."

21 The following discussion concerning reorganization of the Commission and its antecedent history by Carl $\mathrm{I}$. Wheat is of particular interest because of Mr. Wheat's quondam association with the Railroad Commission as its general counsel: "Scope of Railroad Comnission Powers" "This Commission is the outgrowth of the earlier Board of Railroad Commissioners, which was set up in 1880 pursuant to a mandate contained in the new constitution of the previous year, and which languished through 30 years of quite innocuous impotence until, in 1911, it was by constitutional amendnent invested with new and vastly increased powers. Its membership was increased from 3 to 5 , and its authority was extended to include the present broad regulation of public utilities generally, whereas the jurisdiction of the earlier board has been limited to comparatively minor authority over steam railroảds." Wheat, op. cit. supra note 13. 
cumscribed. More than that-it ratified the opinion in the Market Street Railway case. The fact that section 22 was left essentially unchanged constituted an acceptance and an incorporation into the constitutional law of the state supreme court's construction. ${ }^{2.2}$ Such little change as was made in that section and the new provisions of section 23 confirm this.

These constitutional changes subsequently were implemented from time to time by a series of enabling acts which were in a sense the modern successors of the statute of 1880 . Among the first of these was the "Public Utility Act" of 1911' which was re-enacted in 1915 and has been periodically amended ever since. ${ }^{23}$ Since 1911 the legislature has entrusted to the Commission's aegis, gas, electric, water, express companies and motor carriers among others. This method of state action has obtained to date. Only one case ever arose to disturb (but not to alter) the symmetry of this design.

In 1916 the Public Utility Act had as yet made no provision for regulation of common carriers by "motor stage or motor truck".". But in Western Association of Short Line Railroads v. Railroad Commission, ${ }^{25}$ the supreme court apparently was impatient of this negative attitude of the legislature. It overruled the Commission's own modest views of its powers and read into section 22 Commission jurisdiction over motor carriers. The Western Association case arose out of applications by plaintiff, Western Association, to have the Commission regulate the Wichita Transport Co. "which company admitted it was engaged as a common carrier in the business of transporting freight in motor trucks on the public highways of the State of California", and the Peminsula Company which was running an inter-

20 As was said in Pacific Telephone and Telegraph Co. v. Eshleman (1913) supra note 19, 166 Cal. at 651,137 Pac. at 1122: "Yet the framers of the present Constitution repeated the words embraced in the former. We are forced to the conclusion that they used these same words in the sense which had been attached to them by the Supreme Court." Sharon v. Sharon (1885) 67 Cal. 185, 7 Pac. 456, 635, 8 Pac. 709; Thomason v. Ruggles (1886) 69 Cal. 465, 11 Pac. 20; Lord v. Dunster (1889) 79 Cal. 477, 21 Pac. 865; People v. Freeman (1889) 80 Cal. 233, 22 Pac. 173, 13 Am. St. Rep. 122; People v. O'Brien (1892) 96 Cal. 171, 31 Pac. 45; Morton v. Broderick (1897) 118 Cal. 474, 50 Pac. 644; Ex parte Ahern (1894) 103 Cal. 412, 37 Pac. 390; People v. Edwards (1892) 93 Cal. 153, 28 Pac. 831; Palache v. Funt (1884) 64 Cal. 473, 2 Pac. 245; United Railroads v. Superior Court (1915) 170 Cal. 755, 151 Pac. 129, Ann. Cas. 1916E 199.

23 Cal. Stats. Ex. Sess. 1911, p. 18; re-enacted Cal. Stats. 1915, p. 115, as amended.

24 Franchise Auto Freight Assoc. v. Seavey (1925) 196 Cal. 77, 78; 235 Pac. 1000, 1001.

25 (1916) 173 Cal. 802, 162 Pac. 391, 1 A.L.R. 1455. 
city system of auto buses on regular schedule. The Commission had previously declined to entertaim jurisdiction of the applications, resting its conclusions on the twin propositions that there existed neither a constitutional nor a legislative grant of power authorizing it to do so. ${ }^{26}$ Thereafter mandate had been sought from the supreme court which denied the same, "it appearing to the court that the commission had reached and expressed a satisfactory conclusion on both propositions". ${ }^{27}$

The Western Association decision developed out of a new application for a reconsideration of "the question of the constitutional grant of power". For reasons which are not clear from the opimion, the court experienced a change of heart and issued a mandate.

Analysis shows the opinion to be disjointed and eclectic. The first part of section 23 is cited to show that motor carriers are common carriers and public utilities. The second and controlling part of section 23 which designates the legislature as the sole arbiter of regulatory necessity is ignored. The device of contemporaneous construction of section 22 employed in the Market Street Railway case is specially noted with approval, ${ }^{28}$ but this device is then employed in an attempt to bridge entirely separate eras. Thirty-seven years are telescoped and the standards and circumstances applied are not those of 1879 but of 1916 , when the court reasons thus: ${ }^{20}$

"... if the quoted language of Section 22 stood alone as a subject of construction, it would be unhesitatingly held, in the present day, that it conferred powers over all transportation companies, therein including transportation companies of the classes under consideration." (Italics supplied.)

But nowhere in the opinion is there a finding that section 22 was intended in 1879 to include inotor carriers. Although "in the present day", circa 1916, "transportation companies" could have colloquially included motor carriers. But this was not pertinent. Another approach is then essayed. Here the court's reasoning perforce becomes negative. It is unable to find that the organic language includes motor carriers but, on the other hand, it is also unable to find that it ex-

26 Western Association v. Hackett, 8 C.R.C. (1915) 220; United Railroad Co. v. Peninsula Rapid Transit Co., P.U.R. 1915F, 1012.

27 Supre note $25,173 \mathrm{Cal}$. at $804,162 \mathrm{Pac}$. at 391.

28 The court even restated the proposition that the amendment of section 22 in 1911 constituted a re-enactment in light of the decision in the Market Street case.

20 Supre note 25, $173 \mathrm{Cal}$. at 805,162 Pac. at 392. 
cludes motor carriers-therefore the Commission must have jurisdiction. $^{30}$

Applying another patch, the court rationalizes its conclusion as necessary anyhow because of the state legislature's inaction on the subject. $^{31}$ The court's uncertainty, which is understandable also because of its reversal of its own prior decision in this case, becomes even more patent when it discourses at length on the desirability of regulation of motor carriers. It would appear to have found more support for its conclusion in expediency than in the constitution.

Market Street Railway was discussed in the course of the Western Association opinion and the reasoning there approved, but that case was limited as applying only to "transportation companies of whatsoever kind operating exclusively within a municipality". Yet this limitation was but the arbitrary and literal acceptance of an end result without acknowledgment of the controlling facts and principles that had produced such result.

It would seem, however, that the legislature and courts of California have not followed Western Association's treatment of section 22 as conferring such broad powers. In view of the various statutes and amendments thereto subsequently enacted by the California legislature which bespeak power in the legislature to select the public utility or common carrier to be regulated by the Railroad Commission and in the light of the subsequent decisions of the California courts, it would appear that the Western Association case should be limited in its authority strictly to the facts therein. It is significant that in May 1917, a few months after the Western Association decision, the California legislature enacted a statute defining and limiting the term "transportation company"32 and specifically gave the Railroad Commission jurisdiction over the type of carrier involved in the Western Association case. ${ }^{33}$

30 "Assuredly, nothing in the language of the grant excludes them, and no legitimate construction upon the phrase so oft quoted demands this exclusion. It must be and is therefore held that the constitution has granted regulatory powers over such corporations . . . " Ibid., 173 Cal. at 808, 162 Pac. at 393.

31 "No reason appears why such powers should not have been conferred upon it, and multitudinous reasons exist why it should have been conferred." Ibid., $173 \mathrm{Cal}$. at 805,162 Pac. at 392. This piece of judicial legislation was recognized as such in Franchise Auto Freight Assoc. v. Seavey, supra note 24, at 78.

32 Cal. Stats. 1917 , c. 213.

33 This was described in Franchise-Auto Freight Association v. Seavey, supra note 24, $196 \mathrm{Cal}$. at 78, $235 \mathrm{Pac}$. at 1001, where the court somewhat euphemistically describ- 
Civic Center Association v. Railroad Commission, ${ }^{34}$ decided in 1917, follows the Market Street case rather than the Western Association decision. It involved a conflict between municipal and state agency (railroad commission) jurisdiction and was not concerned with the classification of a transportation medium. It noted the "conflicting provisions of the constitutions" and adopting the reasoning and conclusion of the Market Street case, it decided in favor of the municipal jurisdiction. No other point pertinent here was involved, nor was the Western Association case even discussed or quoted. That decision, quite obviously, was cited only because it had approved the Market Street case on the territorial jurisdiction point.

The various decisions of the supreme court handed down thereafter indicate a legislative and judicial limitation upon the powers of the Railroad Commission both as to types of public utilities and common carriers. ${ }^{35}$ However, the supreme court did on one occasion (albeit unsuccessfully) follow the conclusion of the Western Association case that section 22 was self-executing and gave the Commission control over all carriers, public or private. Frost et al. v. Railroad

ing this development as "procedural" stated: "Prior to 1917, the Railroad Commission exercised no jurisdiction over transportation companies operating as common carriers of freight or passengers over the public highways by motor-stage or motor-truck. In December 1916, this Court held that under Section 22 of Article 12 of the constitution, as amended 1911, the Railroad Commission was vested with the jurisdiction and the duty to regulate rates and charges of such carriers of freight and passengers by motortruck; that this provision of the constitution could not be rendered nugatory by the omission of the legislature to prescribe procedural provision for the carrying out thereof; and a peremptory writ of mandate was issued requiring the Railroad Commission to assume and exercise its jurisdiction over such carriers. (Western Association of Short Line Railroads v. Railroad Commission, 173 Cal. 802, 1 A.L.R. 1455, 162 Pacific 391). Thereupon the Auto Stage and Truck Transportation Act was enacted by the legislature to provide the procedural rules for the exercise of such jurisdiction. (Stats. 1917, p. 330.)"

34 (1917) 175 Cal. 441, 166 Pac. 351.

35 In City of Pasadena v. Railroad Commission of California (1920) 183 Cal. 526, 533, 192 Pac. 25, 28, the court reviewed the authority of the Railroad Commission: "The subject of similar powers over all other classes of public utilities carried on by private corporations or persons is covered by the provisions of section 23 , as we have seen. The provisions of section 22 should not be extended beyond the matters included in the context and the subject matter of the article in which it occurs." In City of San Mateo v. Railroad Commission (1937) 9 Cal. (2d) 1, 6, 68 P. (2d) 713, 715, referring to sections 22 and 23, the court said: "The powers thus conferred have been declared to be unlimited, provided the legislative act conferring additional powers on the conmission shall relate to matters cognate and germane to the regulation of public utilities." (Citing Esbleman case.) To same effect Morel v, Railroad Commission (1938) $11 \mathrm{Cal}$. (2d) 488, 81 P. (2d) 144. 
Commission $^{36}$ involved the constitutionality of the Auto Stage and Truck Transportation Act of 1917 as amended in 1919, in so far as it required a private or contract carrier to obtain a certificate of public convenience and necessity from the Commission. The Commission's jurisdiction was there sustained on the ground that the term "transportation companies" as used in section 22 necessarily gave it power over all carriers, common or private. Literal interpretation had reached a reductio ad absurdem. There too, patently following the method of the Western Association case, the desirability of private carrier regulation was stressed and the doctrine of expediency was used as justification. On review by the Supreme Court of the United States this reasoning was apparently rejected. ${ }^{37}$ That court reversed and held that a private carrier could not be brought within a common carrier classification and that such a course was in violation of the Federal Constitution as constituting the taking of private property without due process of law. ${ }^{38}$

In 1932 the Supreme Court of California in interpreting a related section of the constitution took a view directly opposite to that followed in Western Association. It refused to apply the rule of expediency and substitute judicial legislation for lack of statutory legislation. People v. Duntley ${ }^{30}$ was an appeal from a judgment for the defendant in an action to recover highway transportation taxes levied on a company operating auto trucks used for transportation of property allegedly "as a common carrier over any public highway in State between fixed termini or over a regular route". The defendant, which transported oil, claimed it was a private contract carrier and not within the scope of the Transportation Act. It was upheld by the court on the ground that if it had been the intention of the people of the state to regulate all carriers, the constitution would have so provided. ${ }^{40}$

The various statutory enactments for definition and implementation of the term "transportation companies" were also recognized as

36 (1925) 197 Cal. 230, 240 Pac. 26.

37 Frost Trucking Co. v. Railroad Commission (1926) 271 U.S. 583, 589.

38 Accord: Haynes v. McFarlane (1929) 207 Cal. 529, 279 Pac. 436; Forsyth v. San Joaquin Light \& Power Co. (1929) 208 Cal. 397, 281 Pac. 620.

39 (1932) 217 Cal. 150, 17 P. (2d) 715.

t0 Accord: Lang v. Railroad Commission (1935) 2 Cal. (2d) 550, 42 P. (2d) 639; Morel v. Railroad Commission, supra note 35. 
otherwise controlling in Forsyth v. San Joaquin, etc..$^{41}$ and in Asbury, etc. v. Railroad Commission. ${ }^{42}$

As recently as May 1943, the California Supreme Court had occasion to pass upon the question of the jurisdiction of the Railroad Commission over common carriers of a kind which were not specifically described in the constitution or specfically provided for by the legislature. In re Martine $z^{43}$ was decided by unanimous court. There the petitioner had been convicted in the Police Court of the City of Sacramento for violating a inunicipal ordinance regulating the fixing of rates for taxicabs. The petitioner sought his discharge on a writ of habeas corpus, contending that the ordinance was unconstitutional upon the ground that exclusive power to fix such rates was vested in the Railroad Commission.

In an opinion notable for its analysis of the development of the Public Utilities Act, the court held that the Commission inust first be given a specific legislative mandate to act before it could exercise jurisdiction over a particular class of common carrier.

The point of the Martinez case is not that a taxicab operation within a inunicipality was involved, but that the supreme court reaffirmed the principle that the Commission possessed no inherent power but only such jurisdiction as was specifically given to it. To argue otherwise would be to argue that the sole function of the state legislature is to confer upon the Commission the power to regulate local carriers that otherwise would be subject to nunicipal regulation and that, outside of municipal areas, the legislature had no function in this field.

It is notable that at the request of the court, the Railroad Commission of California filed a brief amicus curiae in which it agreed with the court's conclusion as to its limited jurisdiction, ${ }^{44}$ and stated that section 22 "is not a direct grant of power to fix rates for all kinds of transportation services....." 45

41 Supra note 38 .

42 (1941) 18 Cal. (2d) 105, 109, 114 P. (2d) 573, 575.

13 (1943) 22 Cal. (2d) 259, 138 P. (2d) 10.

14 "In amicus curiae brief filed in this proceeding at the request of the Court, the Railroad Commission is in accord with our conclusions and under section 23 of Article 12 of the Constitution it is only such power to regulate public utilities at a fixed rate as shall be conferred upon it by the Legislature." In re Martinez, ibid., 22 Cal. (2d) at 262, 138 P. (2d) at 12.

45 "Its [the Commission's] consistent action in this respect lias been premised upon the behef, as developed in the discussion above, that section 22 of Article XII of the 


\section{THE PRESENT PATTERN}

The steadily widening range of the Public Utilities Act ${ }^{40}$ from the date of its prototype in 1880 through the various amendments would indicate substantial legislative activity through the years. These numerous grants of power by the legislature have covered many types of transportation and public utilities and have detailed the desired regulation in each case. ${ }^{4 i}$ Today the Commission regulates such modes of for-hire surface transportation as rail, highway and water and also such public utility businesses as warehousemen, wharfingers, water, gas, electric and telephone companies.

The various specific enactments of the legislature are inconsistent with the view that the jurisdiction of the Commission over transportation companies is all-inclusive. Nor can the explanation be that the purpose of all this legislation was to fill a void created by the unparalleled self-restraint of the Commission. When we examine the whole pattern of enactment, constitutional and legislative, we see that the legislature makes specific provision for action by an appropriate

Constitution is not a direct grant of power to fix the rates for all kinds of transportation services, and that the Legislature has not in fact given the Coinmission power to regulate any type of passenger stage service other than one falling within the fixed termini or regular route category described in section 21/4 of the Public Utilities Act." (Commission's Brief, p. 12.)

46 PuBLIC UTILITIES ACT, re-enacted 1915, as amended.

47 This includes the Act For Regulatron of WatzR Companies (Stats. 1913, c. 80, p. 84, as amended), Motor Carring Transportation Agent Act, Hrguway Carretris Act, and Citr Carriers Act. The Poblic Uturitres Act 6386, Section 1 reads in part: "This Act shall be known as 'the public utilities act' and shall apply to the public utilities and the public services herein described and to the commission herein described and to the commission herein referred to." Section 2-Definitions: ". . . (I) The term 'common carrier' when used in this act, includes every railrond corporation; street railroad corporation; express corporation; freiglit forwarder; dispatch, sleeping car, dining car, ... and every other car corporation or person, their lessees, etc. . . . (dd) The term 'public utility,' when used in this act, includes every common carrier, toll bridge corporation, pipe line corporation, gas corporation, electric corporation, telephone corporation, telegrapl corporation, water corporation, wharfinger, warehouseman, and heat corporation, where the service is performed for or the counmodity delivered to the public or any portion thereof." Section 21/4-Additional definitions: "(a) The tern "passenger stage' includes every stage, auto stage, or other motor vehicle. . . . (b) 'Passenger stage corporation' is common carrier over public highway." Section 23/4: "The teran 'highway cominon carrier' refers to a carrier over a public lighway." An Amendment of 1941 provides that no highway common carrier may operate without Railroad Commission supervision and further provides for issuance of certificates of convenience and necessity by the Commission. The Mator Transportation Broker LAw Act 6939 (c), Section 2 defines "motor carrier" as transportation oyer public highways of California. 
state body with respect to particular kinds of common carriers or public utilities as it goes along.

This is also true of aviation. In a separate series of enactments found under Aircraft Acts Nos. 148 to 152, the Legislature of California concerned itself with the problems raised by aviation. A review of this legislation reveals that the legislature was interested only in licensing and in registration in accordance with federal standards and that it had left the matter of regulation to the federal government. In fact the Aircraft Act provides that if the federal government should legislate on the same subject matter the Act shall be void. ${ }^{45}$ The California Air Navigation Act (Act 15) is concerned with licensing. It would further appear that the legislature has clearly indicated that at least for the time being, it prefers federal regulation of intrastate air transportation. ${ }^{49}$

\section{CONCLUSION}

As we have seen, except for its initial constitutional grant of limited authority over railroads, the Commission throughout its career has been essentially the creature of the legislature. In truly democratic fashion its powers and form from the beginming have been determined by its contemporaries in accordance with their wants as they then saw them.

It therefore may be concluded that

1. The Railroad Commission has no jurisdiction over air transportation companies under the constitution unless the same is specifically provided for by the legislature.

2. The Railroad Commission has no jurisdiction over air transportation companies under the Public Utility Act or under any other state statute.

$48 \$ 13$ of Act 148.

40 Section 5(a) reads as follows: "It shall be unlawful for any person after the execution date of this Act to operate or cause to be operated, for the transportation of passengers for hire, any aircraft between fixed termini over a route entirely within the State unless such person holds a Federal certificate of authority". (This Act went into effect 1933 and was thereafter re-enacted in 1939, 1941 and 1943.) Section 7 of this Act makes all local rules secondary to federal rules and regulations. 